\title{
ELEKTROMOS AUTÓK TÖLTÉSE
}

\author{
Boros Rafael Ruben \\ Ph.D. hallgató, Miskolci Egyetem, Fizikai és Elektrotechnikai Intézet, \\ Elektrotechnikai és Elektronikai Intézeti Tanszék \\ 3515 Miskolc, Miskolc-Egyetemváros, e-mail: elkruben@uni-miskolc.hu \\ Jósvai Marcell \\ villamosmérnök alapszakos hallgató, Miskolci Egyetem, Fizikai és Elektrotechnikai Intézet, \\ Elektrotechnikai és Elektronikai Intézeti Tanszék \\ 3515 Miskolc, Miskolc-Egyetemváros, e-mail: josvaimarcell@gmail.com
}

\begin{abstract}
Absztrakt
A tanulmány bemutatja a megvásárolható elektromos autókhoz tartozó korszerü töltöberendezéseket, töltöállomásokat, amelyek hazánkban is elterjedté váltak. A kutatás továbbá részletesen tárgyalja az MSZ EN 61851 szabvány által meghatározott töltési módokat, ezek alkalmazását. Kiemeli a fontosabb paramétereket, amelyre a telepités során ügyelni kell. A piacon kapható elektromosautó-töltő csatlakozó típusok összehasonlitására is sor kerül, mivel jelen pillanatban nincs olyan univerzális töltöfej, amely mindegyik elektromos autóval kompatibilis lenne. A töltöfejek védelmi rendszerét, kommunikációját is ismerteti a cikk, hiszen fontos szempont a beleset-megelözés. Ezen felül annak a lehetösége is bemutatásra kerül, hogy napelem segitségével, hogyan tölthetöek az autók és egy adott hálózaton mennyi elektromos autó tölthetô. Mindemellett kifejti a tanulmány, hogy a megnövekedett számú elektromos autók milyen mértékben növelik meg a hálózat kiterheltségét.
\end{abstract}

Kulcsszavak: napelem, elektromos autó, töltöpont, töltöfejek, napelemes töltöpont

\begin{abstract}
The study presents the modern charging equipment and charging stations for electric cars that can be purchased, which have become widespread in Hungary as well. The research also discusses in detail the charging methods defined by the MSZ EN 61851 standard and their application. Highlights the most important parameters to consider during installation. A comparison of the types of electric car charger connectors available on the market will also be made, as there is currently no universal charging head that is compatible with all electric cars. The protection system and communication of the filling heads are also described in the article, as accident prevention is an important aspect. In addition, the possibility of how cars can be charged with a solar cell and how many electric cars can be charged on a given network is also presented. However, the study explains the extent to which the increased number of electric cars is increasing the load on the grid.
\end{abstract}

Keywords: solar panel, electric car, charging station, charging heads, solar charging station

\section{Bevezetés}

A világunk egyik legnagyobb problémája a környezetszennyezés. Ennek a legfőbb kiváltó oka az ipari tevékenység és az erőmüvek, fütőművek károsanyag kibocsájtása, amelyhez, merőben hozzájárulnak a hagyományos, belső égésủ motorral üzemelő jármüvek is. Az emberek manapság próbálnak környe- 
zettudatosabban viselkedni és különféle eszközöket használnak, hogy környezetbarátabbak legyenek és törekednek arra, hogy minél kisebb ökológiailábnyomot hagyjanak maguk után. Az laikusok többsége azt gondolja, hogy az elektromos hajtással rendelkező járművek használatával környezetbarátabbak, mint a hagyományos belső égésủ motorral rendelkező járművet használó társaik. Ám ez magyarországi viszonylatban nem feltétlenül igaz.

Az elektromos jármüvekben található akkumulátor legyártása, a töltéshez szükséges energia előállítása, esetleges szállítása (importálása), annyi károsanyag kibocsájtást vonz maga után az autó teljes élethosszára kivetítve, hogy az ökológiai lábnyom mérete, szinte ugyanakkora, ha nem nagyobb, mint a benzin és dízel üzemű autóké (Boros et al., 2021). A skandináv országokban, mint pl. Svédországban, ahol a megújuló energia nagy mértékben rendelkezésre áll, és a villamosenergia termelés döntő részét ezekből a forrásokból nyerik. Ezekben az országokban az elektromos hajtású jármüvek használata egy ténylegesen megtérülő beruházás. Ezzel ellentétben Magyarország nem rendelkezik kellő kapacitással, nemhogy megújuló energiaforrások terén, de még a nem megújuló energiaforrásokat használó villamosenergiatermelő kapacitása sem elegendő az igények kielégítésére így Magyarország kénytelen villamosenergiát importálni a környező országokból. Valószínüleg az importált energia sem megújuló energiaforrást használva lett megtermelve, szóval a környezet terhelést tekintve semmivel sem jobb az a villamosenergia, mintha az Magyarországon lett volna elóállítva egy széntüzelésü erömüben. Az átlagembert viszont ez a szempont foglalkoztatja a legkevésbé. Öket jobban foglalkoztatja a potenciális jármüre vonatkozó problémák, mint például a jármü hatótávolsága, a töltési lehetőségek, a töltőfajták vagy az akkumulátor élettartama. Emellett a vásárlót különféle kiváltságokkal próbálják motiválni a vásárlásra, mint például ingyenes parkolás, ingyenes töltő pontok, állami támogatás az autó megvásárlásához stb. Részben ezeknek a kedvező feltételeknek köszönhetően az utóbbi időkben nőtt az elektromos és a hibrid hajtású autók száma Magyarországon.

\section{Elektromosautó-töltő berendezések}

Az elektromos autók akkumulátorát rendszeresen fel kell tölteni, hiszen ez biztosítja a jármű energiaellátását. Ezek az akkumulátorok nagy (16 kWh-tól akár 60/85 kWh-ig) kapacitással rendelkeznek, ezáltal sok energiát képesek tárolni. Ezt az energiát az elektromos hálózatból a töltőkábelen keresztül lehet az akkumulátorokba vezetni. A töltés természetesen időt vesz igénybe, nem úgy, mint a szénhidrogén meghajtású járműveknél, hogy csak beáll az autó a töltő állomásra és két perc után távozhat is. Ez az idő attól függ, hogy egységnyi idő alatt mennyi villamos energiát tudunk az akkumulátorba tölteni. Vagyis mennyi áramot tud az elektromos hálózat biztosítani és mennyit képes a jármủ elektromos rendszere fogadni.

Azt, hogy mekkora áramot tud fogadni az autó a fedélzeti töltő teljesítményétől függ. Ez határozza meg, hogy mekkora maximális töltőáram fogadására képes a jármü. Hiába van ugyanis olyan nagyteljesítményű töltőnk, ami akár $22 \mathrm{~kW}$ töltési energia leadására képes, ha az autó saját töltője csak 3,6 $\mathrm{kW}$ teljesítményü. Az optimális megoldás az, ha az autónak a hálózati energiát biztosító töltőpont és a jármủ saját fedélzeti töltője hasonló teljesítményüek.

A fedélzeti töltő egy meglehetősen bonyolult és drága elektronikus rendszer, ami tartalmaz egy AC/DC konvertert is, ami a váltóáramot egyenárammá alakítja. Feladata fogadni és átalakítani az akkumulátor töltéséhez szükséges elektromos áramot, amit a töltőpontok biztosítanak. Az legtöbb autóban a fedélzeti töltőt utólag nem lehet nagyobb teljesítményüre cserélni, ezért kiváltképp fontos, hogy a felhasználó tisztában legyen azzal, hogy ez a szerkezet milyen mértékben befolyásolja a töltés gyorsaságát és ezáltal a jármü használati értékét. Ha a felhasználó szeretné, hogy minél rövidebb ideig 
tartson a töltés érdemes nagyobb teljesítményű fedélzeti töltővel rendelni az autót. A különbséget a gyorstöltésnél lehet észre venni, amikor nagy töltőteljesítmény áll a rendelkezésünkre és a töltési idő attól függ, hogy ezt a teljesítményt mennyire tudja hasznosítani az autó.

A töltéshez használt töltőpontok, amelyekhez a töltőkábellel csatlakoztatjuk a gépkocsit, tulajdonképpen egyfajta „intelligens kábelnek” nevezhetők. Angol elnevezésük EVSE - Electric Vehicle Supply Equipment - amit Elektromos Jármüvet Tápláló Eszköznek lehetne szó szerint fordítani, magyarosabban Elektromos Autó Töltő Készüléknek mondhatjuk (villanyautosok.hu/elektromostoltoallomasok-magyarorszagon, 2021).

Az EVSE tulajdonképpen az az eszköz, amit szinte mindenki egyszerüen csak elektromos autó töltőnek hív. Igazából az EVSE az az alkatrész, ami hasonlít a laptopok töltőjén lévő „dobozra”. Ezt minden autóhoz adják, és a „dobozból” kimenő egyik kábelt a konnektorba, a másikat pedig az autóhoz csatlakoztatva tölti az akkumulátort. Ugyanilyen EVSE a falra szerelhető és fixen beköthető töltő is, de a közterületeken található ELMÜ oszlop is EVSE (villanyautosok.hu/elektromostoltoallomasok-magyarorszagon, 2021).

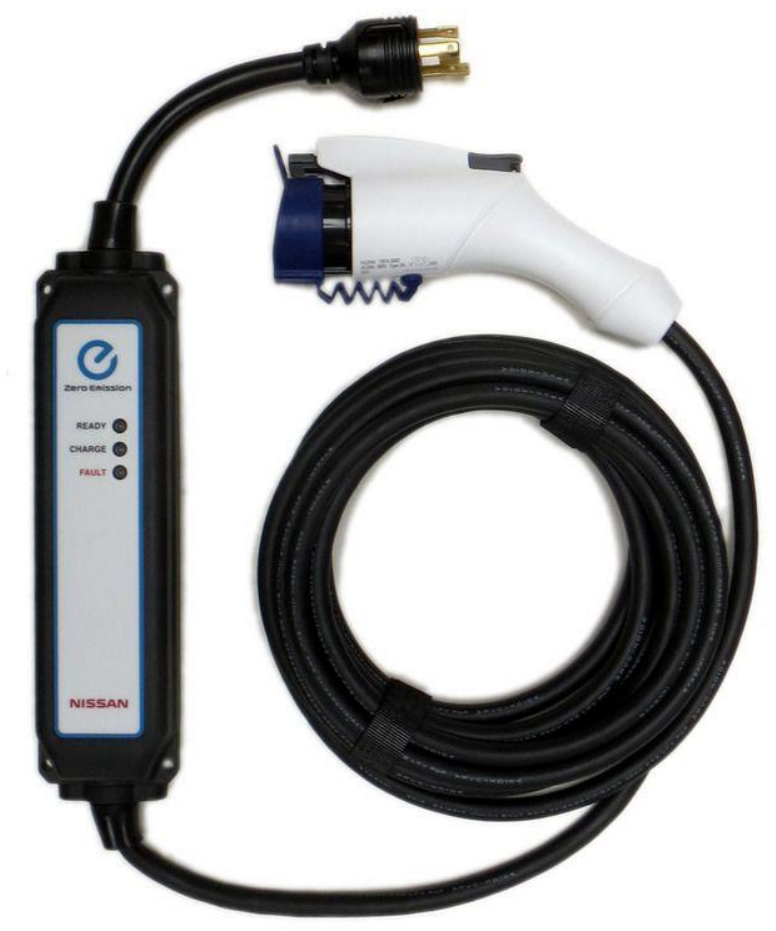

1. ábra. Falra szerelhetö EVSE töltö egység.

Ez az EVSE azért nem a „töltö”, mert a töltő igazából az autóban van, ami a fedélzeti töltő. Az autó rendszere tartalmazza ugyanis azt az elektronikát, ami a kábelen beérkezö váltakozó áramból az akkumulátorba tölthető egyenáramot állít elő.

Az EVSE elsődleges feladata az, hogy garantálja a töltés biztonságát. Töltéskor olyan nagy értékü áramok folynak át a hálózatból az autó akkumulátoraiba, melyek életveszélyeseknek számítanak, ebből kifolyólag a biztonság prioritást élvez minden szempont előtt. A töltőpontok vezérlői, amelyek maguk is kis mikroszámítógépek, egy meghatározott protokoll szerint, egy külön vezetéken, úgyneve- 
zett Control Pilot jel segítségével kommunikál a jármü fedélzeti töltőjével. Az EVSE meghatározza, hogy mekkora energia fogadására képes az autó és az elektromos hálózat mekkora töltőáramot tud biztosítani a töltéshez. Ellenőrzi, hogy a töltőkábel mekkora áramot tud biztonságosan vezetni, azt is figyeli, hogy a védőföldelés csatlakoztatva van-e a jármühöz, és még több, további, a biztonság szempontjából fontos paramétert is vizsgál. Csak akkor kapcsolja az EVSE a jármü töltőjére a hálózati feszültséget és az autó töltője is csak akkor fogadja azt, ha mindent rendben talál (villanyautosok.hu/elektromos-toltoallomasok-magyarorszagon, 2021).

Az elektromos jármüvek töltésére vonatkozó szabvány 4 féle módot különböztet meg (eon.hu, 2021; villanyautosok.hu, 2021; gateconnection.hu, 2021):

- Mode1 - Lassú töltés háztartási dugaljból, beépített védelem nélkül. Nem jellemző alkalmazás.

- Mode2 - Lassú töltés (2,3-3,5 kW). Jellemző töltési idő 8-12 óra háztartási dugaljból, a kábelbe szerelt elektronikus vezérlőeszközön (ICCB) keresztül. A töltőkábel az elektromos autó alaptartozéka.

- Mode3 - Normál töltés (7,4-22 kW). Váltóáramú (AC) töltés töltőberendezésről, beépített vezérlő és védelmi funkciókkal. Becsült töltési idő az autó fedélzeti töltőjétől függően, 1,5-7 óra. A $22 \mathrm{~kW}$-os verziókra a gyorstöltő megnevezést is használják.

- Mode4 - Nagy teljesítményü gyorstöltés (40 kW felett). Egyenáramú (DC) töltés, villámtöltésnek is nevezik. Töltési idő az akkumulátor méretétől függően akár 30 perc a töltöttség 80\%-ig.

Mivel a Mode1 töltők nem kommunikálnak a jármüvel, ezért ezeket elektromos autóknál nagyon ritkán használják.

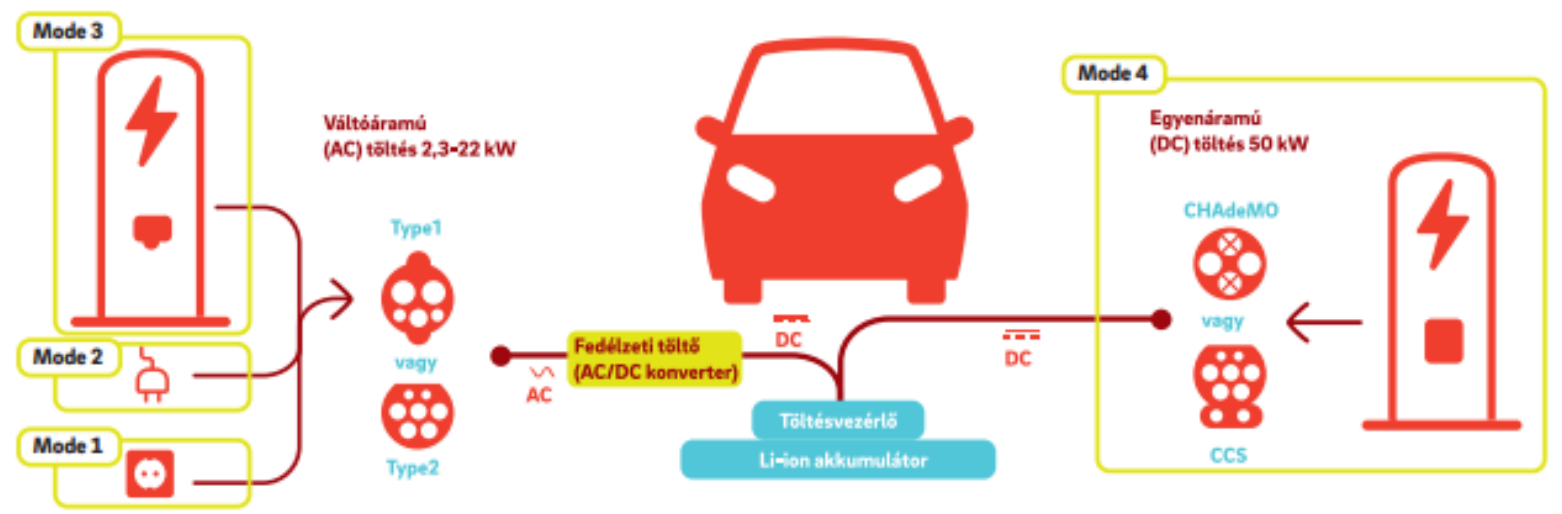

2. ábra. MSZ EN 61851 szabvány által meghatározott töltési módok.

Az elektromos autózás nagy előnye, hogy az autó feltöltéséhez nem kell benzinkútra járni. Egy villanyautó szinte bárhol feltölthető, ahol van egy legalább 10-16 amperes konnektor. Ez azt jelenti, hogy az elektromos autókat akár otthoni konnektorról is lehet tölteni, igaz nem ez lesz a leggyorsabb töltési opció, de arra tökéletes, hogy az autó az éjszaka alatt részben, vagy teljesen feltöltsön. Ezek a töltők általában a lassú töltés (Mode2) kategóriájába sorolható. 1 vagy 3 fázisról, fázisonként 10-16 amperrel töltik az autó akkumulátorát. Így teljesen lemerült állapotról 8-10 óra alatt töltik fel az autót. A sebesség ezeknél a töltőknél nem mérvadó, hiszen az autó éjszaka úgyis áll, ráadásul az autósok többsége nem teljesen lemerült akkumulátorral ér haza, így a töltés sem tart a maximális ideig. Ezek a töltők kizárólag AC (váltóáramú töltők), melyek Type1 vagy Type2 csatlakozóval kapcsolódnak az autóhoz, és jellemzően 2,3-3,5 kW leadására képesek. A Mode2 töltőkkel elvileg bármilyen 230V-os háztartási 
konnektoron keresztül kapcsolódhatnak az elektromos hálózathoz. A gyakorlatban ez nem teljesen így van. A háztartási konnektorokat ugyanis nem olyan folyamatos, nagy terhelésre tervezték, amit egy autó Mode2 töltője jelent. Ezért ezekhez a töltőkhöz is célszerű kiépíteni olyan, érintésvédelmi kapcsolóval (FI relé) ellátott, ipari kivitelü konnektort a garázsban, amely elviseli a folyamatos, nagyteljesítményü igénybevételt. A Mode2 töltők legjobb példái az elektromos jármüvekhez gyári tartozékként adott töltőkészülékek. Minden villanyautóhoz jár egy gyári töltő, ami a középkategóriás autók (pl. Nissan LEAF) esetén többnyire 10 A-es teljesítménnyel képes tölteni az autó akkumulátorát. Ezt a töltőt érdemes az autóban tartani, mert ezzel bárhol, majdnem bármelyik konnektorból lehet áramot vételezni. Ezek egyik végén egy villásdugó van, amit a konnektorba kell dugni. A kábelre van építve egy kis doboz (EVSE) is, ami a vezérlő elektronikát rejti. Ezen LED-ek, vagy egy kis kijelző mutatja a töltési folyamat pillanatnyi állapotát. A kábel másik végén egy nagyméretü, speciális csatlakozó van, amivel a töltőt a jármü töltőbemenetére lehet kapcsolni. Biztonsági okokból tilos bármilyen átalakítót, hosszabbítót, elosztót vagy toldalékot használni a töltőkábelhez, azt közvetlenül az autó töltőbemenetére szabad csak csatlakoztatni! A gyártók azért limitálják a gyári töltőket 10 A-ben a töltőáram nagyságát, hogy a töltő gyengébb teljesítményü konnektorokkal is használható legyen (eon.hu, 2021; villanyautosok.hu, 2021; gateconnection.hu, 2021).

A fali töltők az otthoni töltés kényelmesebb változata. Ezek a töltők mindig fixen bekötve csatlakoznak az elektromos hálózathoz. A töltő kábele is állandóra be van kötve, így csak a csatlakozót kell leemelni és az autóba dugni. Ezek a fali töltők képesek 3,7 kW-tól egészen $22 \mathrm{~kW}$, de akár még ennél nagyobb teljesítménnyel is tölteni az elektromos jármüveket. Lehetnek 1 fázisú (230V), vagy 3 fázisú ( $3 \times 230 \mathrm{~V})$ berendezések. Ezek a fali töltők Mode3 típusúak, azaz még mindig váltakozó áramú berendezésről beszélünk. Ilyen fali gyorstöltőt bárki felszerelhet a garázsába, vagy elhelyezhető a munkahelyi parkolóban is. Hogy mekkora teljesítményü legyen a töltő, annak a szabvány elöírásain kívül csak a jármü fedélzeti töltője és az ingatlan villamos hálózata szab határt. Fontos számításba venni, hogy van- e a rendszerben elegendő tartalék egy ilyen nagy teljesítményü fogyasztó beépítésére. Lehetséges, hogy bővítés nélkül nincs arra kapacitás, hogy beépítsék a töltő készüléket, ezt mindenképp szakemberrel kell ellenőriztetni telepítés elött, mivel a rosszul méretezett vezetékek melegedhetnek, rosszabb esetben pedig ki is gyulladhatnak, amik jelentős anyagi kárt jelentenek.

A köztéri, nyilvános töltőállomások többsége is Mode3 gyorstöltő. Ezek a gyorstöltők általában kétféle módon csatlakoztathatók az autóhoz. A fix kábeles változatok esetében a töltőkábel egyik vége fixen be van kötve a töltőpontba, a másik végére pedig az autó töltőbemenetéhez illeszkedő csatlakozó van szerelve.

A másik megoldást, csatlakozósnak nevezzük. Ebben az esetben a töltőponton egy csatlakozó aljzat van, amihez külön töltőkábelt kell használni. Ennek egyik végén olyan csatlakozó van, ami illeszkedik a töltőponton lévő aljzatba, a másik végén pedig olyan, ami az autó töltőbemenetéhez passzol. Ennek a megoldásnak a nagy előnye, hogy ezt a töltőkábelt a töltőpontról le lehet csatlakoztatni, az autóban lehet tartani és bárhol, bármikor használni. A töltőpontok aljzatai ugyanis egész Európában szabványosak, így ugyanazzal a kábellel bármely nyilvános töltőhöz lehet csatlakozni.

A töltőpontok esetében elöírás, hogy azokat olyan áramkörbe szabad csak bekötni, amely szabványos védőföldeléssel, túláram- és áramütés elleni védelemmel (áram-védőkapcsoló, vagy FI relé) rendelkezik. Ez utóbbit el lehet helyezni az ingatlan elektromos elosztószekrényében, vagy magában a készülékben is.

Ezek közül a töltőpontok közül Magyarországon az ELMÜ által felállított $22 \mathrm{~kW}$-os oszlopok, illetve az E-ON által telepített 11-22 kW-os oszlopok terjedtek el. Mindkettőhöz Type2-es csatlakozón 
keresztül lehet csatlakozni. Az ELMÜ oszlopok többnyire Budapesten és néhány vidéki városban (pl. Miskolc, Sopron) találhatóak (gateconnection.hu, 2021).

Ezeken a kihelyezett töltőoszlopokon nincs kábel, azt minden esetben az autósnak kell vinnie. Amíg a kábel az autóhoz van csatlakoztatva, addig a töltőből sem húzható ki, viszont az autóról való lecsatlakozás után a töltőkábel szabadon kihúzható. Ezért nagyon fontos, hogy a kábelt az autó oldalon is reteszeljük. Azonban ezeken az utcai gyorstöltökön osztozkodnunk kell a többi elektromos autó tulajdonossal, így könnyen előfordulhat, hogy éppen foglalt a töltő amikor mi szeretnénk használni.

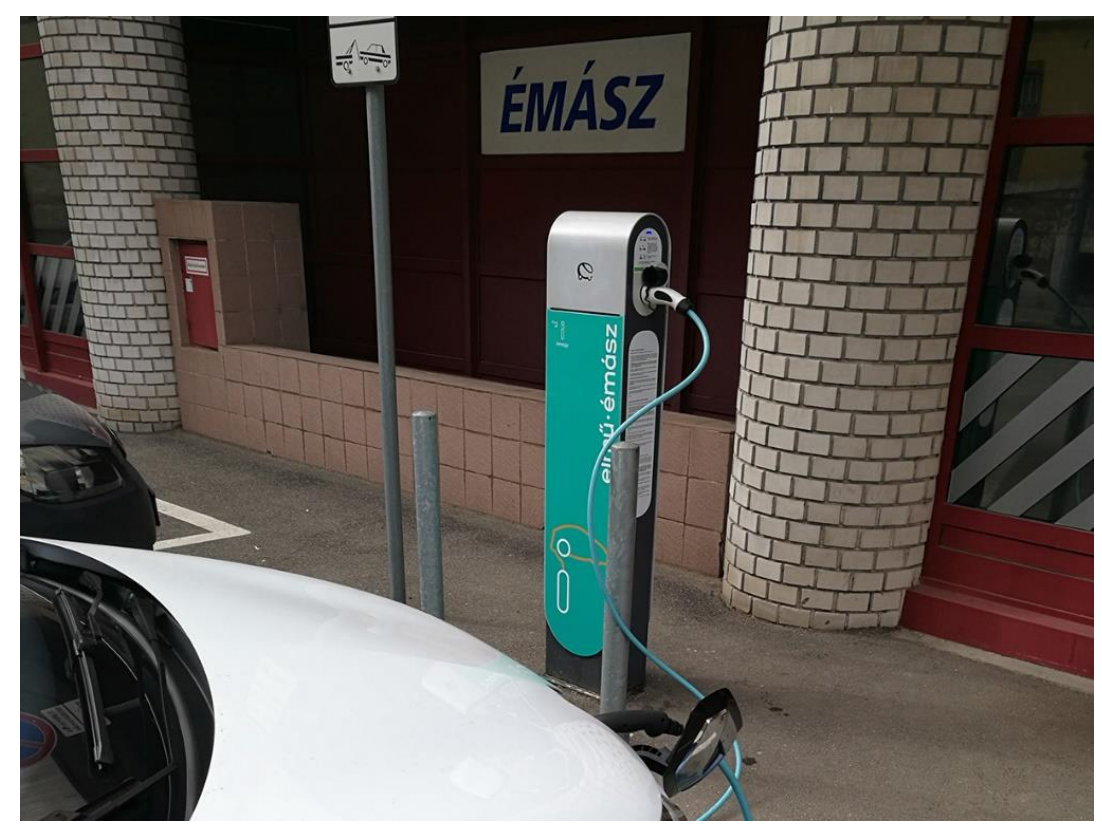

3. ábra. Elektromosautó-töltő Miskolcon a ÉMÁSZ központja mellett.

A 40 kW-nál nagyobb kapacitású töltőket itthon villámtöltőnek nevezzük. Az eddig említett töltőknél, töltési módoknál váltakozó feszültség segítségével töltöttük az autó akkumulátorát. Azonban létezik, olyan lehetőség amikor nagyfeszültségü (450-1000 V) egyenárammal (DC 150-400 A) töltjük az akkumulátort. Ez a villámtöltés nem a jármü fedélzeti töltőjén keresztül történik, hanem egy attól funkcionálisan különböző töltésszabályozón keresztül (eon.hu, 2021).

A villámtöltők legfontosabb feladata, hogy az úton lévő autóst segítsék a mielőbbi tovább haladásban. Ezek egyenáramú töltők nagy beruházás-igényü, drága berendezések ezért általában csak olyan helyeken telepítik, ahol valóban nagyon gyors töltésre van szükség, mint például autópályák mentén.

Az egyenáramú, Mode4 villámtöltőket, úgy alakították ki, hogy az az elektromos autók teljesen lemerült akkumulátorát akár 30-40 perc alatt $80 \%$-ra is fel lehet tölteni. Az akkumulátorok sajátosságai miatt a $100 \%$-kos töltöttségi szint elérése közel ugyanennyi időt vesz igénybe, mivel az utolsó 1520\% az akkumulátor kímélése érdekében rendkívül lassú és ilyenkor az autó már nem használja ki a töltő teljesítményt (villanyautosok.hu, 2021; gateconnection.hu, 2021).

A Mode4 töltők a szabvány elöírása szerint csak fix kábelesek lehetnek, aljzat nincs rajtuk, saját töltőkábellel azokhoz nem lehet csatlakozni. Kivéve, ha váltakozó áramú töltőről van szó, mivel azon található töltő-aljzat. Maga a töltőkábel vastag, robosztus felépítésü, hiszen nagyon nagy áram folyik rajta. 
Természetesen, mint mindennek a villámgyors töltésnek is ára van: az extrém nagy árammal való töltés az akkumulátorokat jobban terheli. Ezért, ha valaki rendszeresen csak villámtöltővel tölti jármüvét, akkor az akkumulátor kapacitása és ezzel együtt a jármüvének hatótávolsága gyorsabban csökkenhet. Ezért célszerü inkább a lassabb, de kíméletesebb hálózati töltést használni, amikor csak lehet és a villámtöltőket csak akkor igénybe venni, ha hosszabb útra indulunk és útközben nincs időnk órákat várni a töltésre.

Az egyenáramú töltéshez a jármüvek is külön csatlakozóval rendelkeznek, vagy olyan kombinált csatlakozóval, amelyekben az egyenáramú töltéshez külön nagyáramú érintkezők vannak kialakítva.

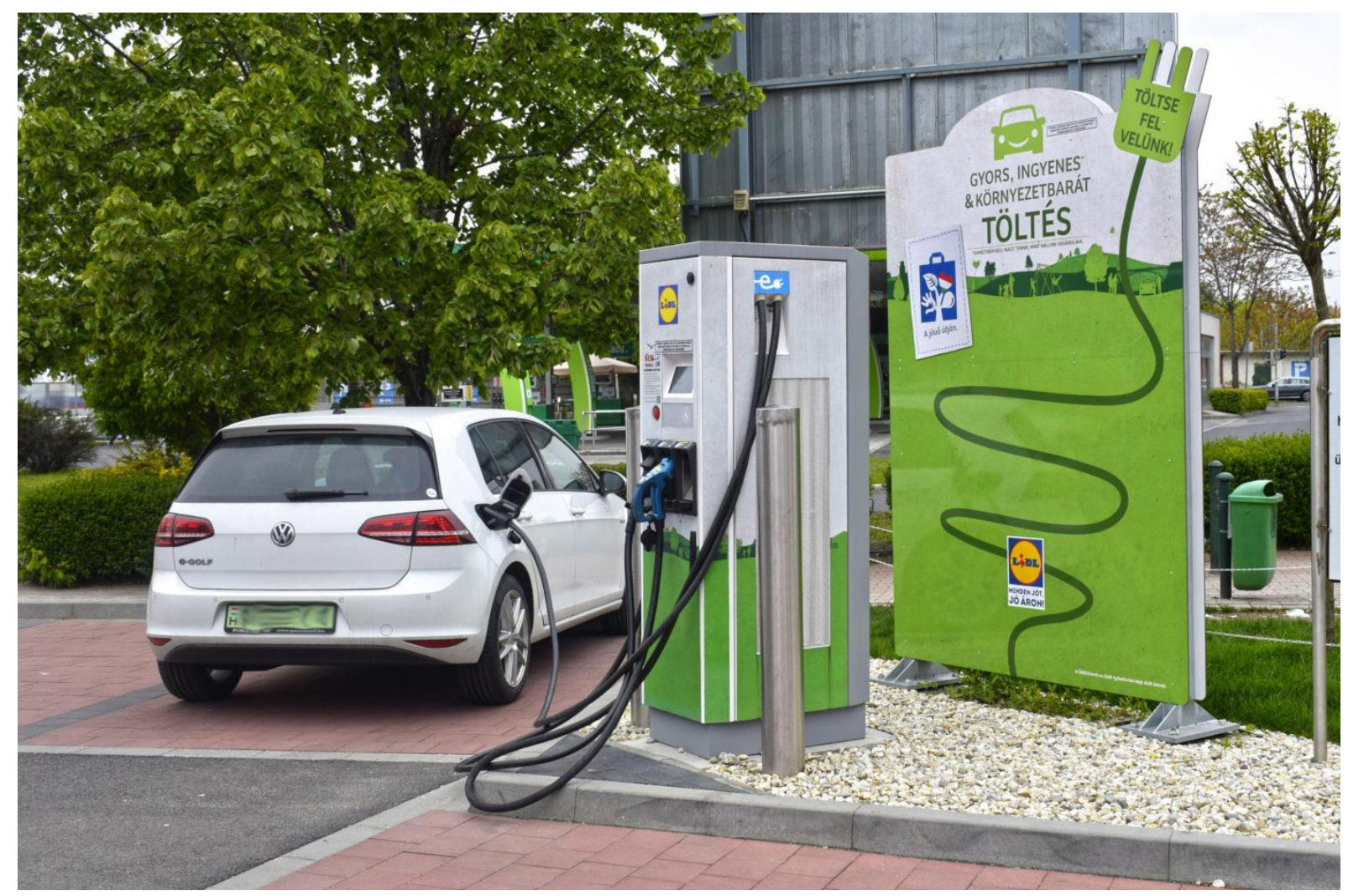

\section{4. ábra. Villámtöltö.}

\section{Elektromosautó-töltő csatlakozó típusok}

A töltéshez szükséges csatlakozóknak többféle típusa létezik a piacon. Különböző kialakítású töltőfejeket használnak váltakozóáramú és egyenáramú töltésnél. Sajnos jelen pillanatban nincs olyan univerzális töltőfej, amely mindegyik elektromos autóval kompatibilis lenne. A következőkben ismertetem a különféle csatlakozó típusokat.

A Mode2 és Mode3 váltakozó áramú töltőkhöz az elektromos autókba jelenleg kétféle csatlakozót építenek be, a Type1, vagy Type2 csatlakozót. Mindig az elektromos jármü gyártójának döntése, hogy melyik szabvány szerinti AC töltőcsatlakozót használja (villanyautosok.hu, 2021; gateconnection.hu, 2021). 
A Type1 csatlakozót (5. ábra), mivel összesen három nagyáramú kontaktussal rendelkezik csak egy fázisú AC töltésre használják. A szabvány szerint, a Type1 típusú csatlakozóknak összesen öt kontaktusa van. Három vastag a nagy áramú töltéshez (a fázis, a nulla és a föld) valamint két vékonyabb kontaktus a Control Pilot és a Proximity Pilot számára. A csatlakozó felső részén egy billenő horgos akasztó is van, ami rögzíti az aljzatban a csatlakozót és megakadályozza annak kicsúszását. Ez a zár egyben egy, a csatlakozóba beépített kapcsolót is müködtet. Így, ha valaki töltés közben mégis kihúzná az aljzatból a csatlakozót, amihez egyébként le kell nyomnia a billenő zárszerkezetet, akkor a beépített kapcsoló bontja az áramkört és a vezérlő azonnal lekapcsolja a kábelről a töltőáramot (villanyautosok.hu, 2021; gateconnection.hu, 2021).

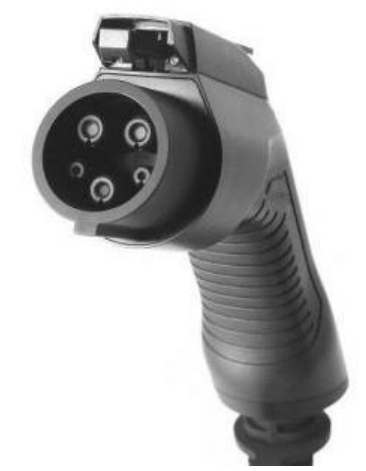

5. ábra. Typel csatlakozó.

A Type2 csatlakozó (6. ábra) 5 nagyáramú kontaktussal rendelkezik: a 3 fázis, a nulla és a föld. Emellett ennél a típusnál is megtalálható a két segédkontaktus, a Control Pilot és a Proximity Pilot jelnek. Ez a csatlakozó nagyobb teljesítményü, 3 fázisú AC töltésre is használható, de csak abban az esetben, ha töltőkábel és a jármü fedélzeti töltője is 3 fázisú. Ennél a csatlakozótípusnál a rögzítést egy, mágneses, vagy motoros múködtetésủ zár-stift biztosítja, ami lehetetlenné teszi a csatlakozó kihúzását az aljzatból töltés közben (villanyautosok.hu, 2021; gateconnection.hu, 2021).

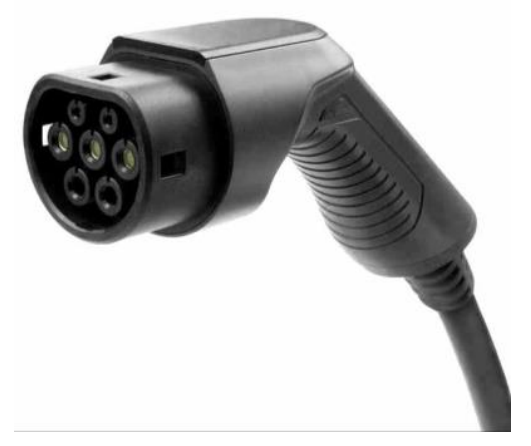

6. ábra. Type2 csatlakozó.

Ha olyan töltőkészüléket használnak, amelybe a kábel fixen be van építve, akkor arra kell ügyelni, hogy a kábel végére a jármübe épített aljzatnak megfelelő csatlakozó legyen szerelve.

Ha a töltőkészüléken csatlakozó aljzat van, akkor olyan kábelt kell használni, amelynek mindkét végén van csatlakozó. Az európai töltőpontokba azonban mindig szabványos Type2 csatlakozó aljza- 
tot építenek. Így függetlenül attól, hogy a jármủ felöli oldalon Type1, vagy Type2 csatlakozó van-e, a töltő felöli oldalon mindig csak Type2 csatlakozó lehet. Ennek megfelelően kétféle töltőkábel létezik: vagy Type2-Type1, vagy a Type2-Type2 típusú kábel (7. ábra). A töltő- és jármü felőli oldalt még a Type2-Type2 típusú kábelek esetében sem lehet felcserélni. A töltőpont felőli oldalon ugyanis mindig „apa”, a jármü felőli oldalon pedig ,anya” típusú csatlakozó van (villanyautosok.hu, 2021; gateconnection.hu, 2021).

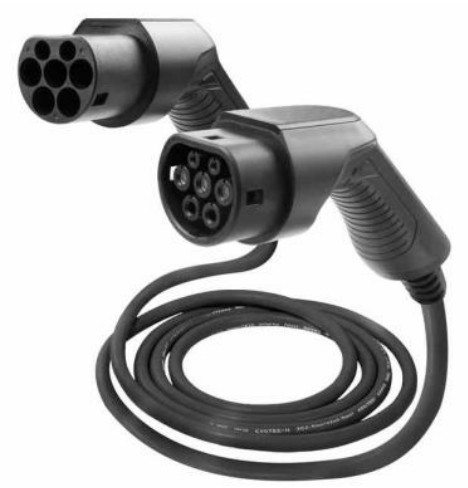

7. ábra. Type2-Type2 töltö, a bal oldali az „, apa”, a jobboldali az „, anya” csatlakozó.

A Mode4 egyenáramú töltők ugye nagyobb feszültséggel és jóval nagyobb áramerősséggel töltik az elektromos jármüveket, mint a Mode3 töltők. Ilyen nagy áramerősségnél még vastagabb vezetékeket és még a csatlakozókban is nagyobb átmérőjű kontaktusokat használnak. Az egyenáramú Mode4 töltőkhöz a Type1 és Type 2 csatlakozók nem alkalmasak. Az egyenáramú töltéshez a gyártók speciális csatlakozókat építenek be a jármübe, ami sok esetben egy külön csatlakozó aljzat az autóban (villanyautosok.hu/elektromos-toltoallomasok, 2021).

Az egyenáramú töltőknek három fajtája terjedt el Európában. Az egyik a japán autógyártók által kifejlesztett CHAdeMO csatlakozójú, amit természetesen leginkább az ázsiai autókban találhatunk meg, mint a Nissan, a Kia vagy a Mitsubishi. A másik kettő fajta csatlakozású töltőt, a Type2 és az ebből a csatlakozóból továbbfejlesztetett CCS csatlakozós töltőt föleg az európai márkák, mint például a $B M W$ és a Volkswagen, autóiban találhatjuk meg (villanyautosok.hu, 2021; gateconnection.hu, 2021).

A CCS (Combo Charging System) vagy másnéven COMBO csatlakozók úgy épülnek fel, hogy egy csatlakozó szolgál a Mode2/ Mode3 váltakozó áramú és a Mode4 egyenáramú töltésre is. Ezt úgy kell elképzelni, hogy egy csatlakozó aljzatba van integrálva a kombinált csatlakozó.

Amikor a jármüvet váltakozó áramú töltőpontról töltik, akkor csak a csatlakozó felső részét használják. Ez lehet Type1, vagy Type2 csatlakozás. Ha azonban egyenáramú töltőhöz akarják csatlakoztatni a járművet, akkor a csatlakozó az alsó, nagy áramokra méretezett kontaktusait is használja a töltő. Attól függően, hogy a kombinált csatlakozó felső része Type1, vagy Type2 típusú, megkülönböztetnek COMBO1 és COMBO2 csatlakozókat (villanyautosok.hu, 2021; gateconnection.hu, 2021).

A Tesla Model $S$ a hagyományos Type2-es csatlakozón keresztül egyenárammal is lehet tölteni, így a Tesla Motors által világszerte kiépített Tesla Supercharger hálózat töltői is ilyen csatlakozóval rendelkeznek (villanyautosok.hu, 2021; gateconnection.hu, 2021).

A csatlakozók egymással természetesen nem kompatibilisek, az átjárhatóság minimális. Egyedül a Tesla készített olyan adaptert, amit az autó és a CHAdeMO csatlakozó közé illesztve a Teslák a CHAdeMO oszlopról is tölthetőek (villanyautosok.hu, 2021; gateconnection.hu, 2021). 
A Magyarországon telepített villámtöltők többsége CHAdeMO rendszerü, vagy ezt a szabványt is támogatja. Az újabban telepített töltők között azonban már többségben vannak azok, amelyek dupla (CHAdeMO és CCS) vagy tripla szabványosak (az előbbi kettő mellett váltóáramú AC töltésre is képesek). Fontos tudni, hogy ezeken egyszerre CHAdeMO és CCS szabványú autó együtt nem tölthető, de némelyiknél lehetőség van a CHAdeMO vagy a CCS töltés mellett a Type2-es csatlakozón keresztül váltóáramú töltésre (8. ábra) (villanyautosok.hu, 2021; gateconnection.hu, 2021).

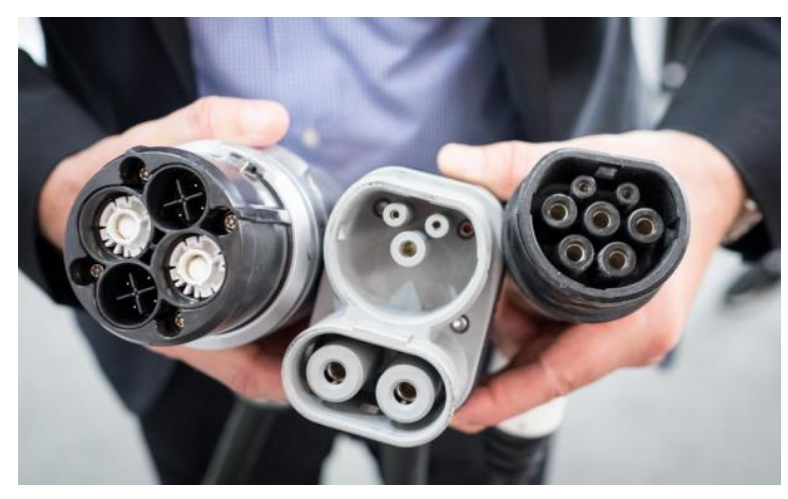

\section{8. ábra. CHAdeMO, CCS és Type2 csatlakozó (balról jobbra).}

Töltőkészülék és töltőkábel vásárlása előtt mindig ellenőrizni kell, hogy az adott autó-típushoz milyen csatlakozóval szerelt kábelt kell használni, mivel tilos bármilyen átalakító, toldó vagy hosszabbító használata a töltőkábelhez! Összegyüjtöttük egy táblázatba néhány elektromos autót és azt, hogy melyik töltőcsatlakozóval rendelkeznek.

1. táblázat. Elektromos autók és a hozzájuk tartozó töltök.

\begin{tabular}{|c|c|c|c|c|}
\hline Elektromos jármü & Type1 & Type2 & CHAdeMO & COMBO 2 CCS \\
\hline BMW i3 (7,4 kW) & & + & & + \\
\hline KIA Soul EV & + & & + & + \\
\hline Mercedes B Class Electronic & & + & & + \\
\hline Mitsubishi Outlander PHEV & + & & + & \\
\hline Nissan Leaf (7.4 kW) & + & & + & \\
\hline Opel Ampera & + & & + & \\
\hline Renault Zoe & & + & + & + \\
\hline Tesla Model S dual charger 20 kW & & + & & \\
\hline Toyota Prius Plus-In & + & & & \\
\hline Volkswagen e-Golf & & + & & \\
\hline
\end{tabular}


A töltőkábelen nagy áramerősség folyik át, amikor tölti a jármüvet, ezért rendkívül fontos ismerni a kábel azon paraméterét, amely megmutatja, hogy mekkora maximális töltóáramot képes elvezetni. Ha nem megfelelö keresztmetszetü kábelt alkalmazunk, akkor az óriási károkat okozhat az autóban és a környezetében. A töltőkábelek csatlakozóiba egy ellenállás van beépítve, amelynek értéke alapján a töltőkészülék és az autó azonosítani tudja, hogy milyen maximális töltőárammal terhelhető a kábel. A készülék mindig csak akkora töltőáramot fog engedélyezni, amekkorára a töltőkábel méretezve van. Ezen okból kifolyólag a töltőkábel is befolyásolhatja a töltés sebességét. Minél nagyobb töltóáramra van méretezve a kábel, annál nagyobb teljesítménnyel lehet tölteni az akkumulátort és így a töltés is gyorsabb lesz. Emiatt célszerübb lehet egy nagyobb kapacitású, 32 amperes töltőkábelre beruházni. Ezek a töltőkábelek valamennyivel drágábbak lesznek, mint a kisebb, 16 amperes teljesítményü töltőkábelek, de ez a többlet költség mindenképp kifizetődő, mivel biztonságosabbak és gyorsabb töltést tesznek lehetővé.

A töltőkábelek felépítését az is befolyásolja, hogy 1 fázisú, vagy 3 fázisú töltőről beszélünk. Az 1 fázisú töltők három, a 3 fázisú töltők, pedig öt vastag vezeték segítségével juttatják el a nagy áramerősségű töltőfeszültséget a jármühöz. Ezek közül a vezetékek közül egy vagy három vezeték (attól függően, hogy 1 vagy 3 fázisú töltőről beszélünk) a fázis(ok), egy vezeték a nulla és egy a védőföld. Ezeken kívül megtalálható egy vékonyabb vezeték, amin a Control Pilot (CP) jelet vezetik, ami a töltőpont vezérlöje és a jármü közötti adatkommunikációért felelös. A töltőcsatlakozókon ezen kívül található egy úgy nevezett Proximity Pilot, magyarul közelítés-érzékelő kontaktus is. Ezen az érintkezőn az ellenállás-értéket méri a töltésvezérlő, ami két fontos információt továbbít az elektronikának. Elsősorban jelzi, hogy a csatlakozó biztonságosan csatlakoztatva van. Ez úgy lehetséges, hogy csak megfelelő kontaktus esetén mérhető az ellenállás értéke, más esetben szakadást mutat. A másik fontos adat az ellenállás értéke, ami arányos a töltőkábel maximális áramterhelésével. A vezérlő ez alapján el tudja dönteni, hogy a kábel biztonságosan milyen maximális áram átvitelére alkalmas. Mindezek után a csatlakozó rögzítésére kerül az aljzatban egy zárszerkezettel, amely megakadályozza annak véletlenszerü kihúzását töltés közben. Ha mindez megvan a Control Pilot jel segítségével elindul a kommunikáció a töltőpont és az autó fedélzeti töltője között és ha minden rendben van, elindul a töltés. A töltökábel vastag, nagyteljesítményü vezetékeire a töltésvezérlő csak azután kapcsol áramot, ha az biztonságosan csatlakoztatva van mind a töltőponthoz, mind a jármühöz és az adatkommunikáció a készülék és a jármü között sikeres.

\section{Napelemről való töltés lehetősége}

Sokan azzal a szándékkal vásárolnak elektromos autót, hogy óvják a környezetet. Ez egy szép gondolat, de ha az elektromos energia, amivel töltjük az autót olyan forrásból származik, mint például szén égetése, akkor nem vagyunk sokkal környezetkímélöbbek, mint azok, akik hagyományos, dízel vagy benzin üzemü autóval járkálnak. Viszont az elektromos energiát lehet megújuló energiaforrásból is nyerni, mint például szél vagy napenergia. Ebben az esetben az villanyautó töltése és használata már szinte annyira környezetbarát amennyire csak lehet. Ezért sokan vannak olyanok, akik napelemes rendszert is telepítettek otthonukba, hogy így oldják meg a töltést.

Kutatásunk során a Wagner Solar nevű cégnél találtunk egy jó és költséghatékony megoldást arra, hogy az autónkat tudjuk a napelemről tölteni. Most ezt a technológiát fogom ismertetni. A technológia, amit a magyarországi cég használ a SolarEdge nevü cég fejlesztette ki. Ennek a technológiának a lényege abban rejlik, hogy egy olyan kettő az egyben invertert alkalmaznak a napelemes rendszerhez, ami egyben az elektromos jármủ töltésére is szolgál. Vagyis, ha ezt az invertert építettjük be a rendsze- 
rünkbe már a telepítésnél tudván, hogy a napelemes rendszert fogjuk használni elektromos autó töltésére, akkor később nem kell egy külön elektromos autó töltésére alkalmas berendezést kiépíteni. Ezen felül ennek az invertnek a használata nem teszi szükségessé az épület villamos hálózat bővítését. Ez azért nagyon előnyös, mivel sokszor az otthoni töltő (falitöltő) telepítése hálózatbővítést igényel.

Egy átlag napelemes rendszerről való töltés, igazából nem más, mint a konnektorról való töltés. A napelem napközben, amikor süt a nap termeli az energiát a rendszerbe, és mivel Magyarországon az áramszolgáltatók úgynevezett szaldós elszámolást biztosítanak a napelemes rendszert létesítőknek, azt az energiát, amit napközben megtermeltünk kivesszük éjszaka a rendszerből. Lényegében az autó ebben az esetben nincs közvetlen kapcsolatban a napelemmel, csak az általa megtermelt energiát fogyasztja el. Ez a szaldós elszámolás azt teszi lehetővé, hogy év végén csak a termelt és fogyasztott energia különbségét kell kifizetni.

A SolarEdge inverter az első olyan inverter a világon, amely napelemes inverter és elektromos autó töltő is egyben. Ezzel az eszközzel pénzt takaríthatunk meg, mivel nincs szükség külön töltő telepítésére, illetve gyorsabb töltés megvalósítására képes, mint a konnektoros Mode2 töltés. Az inverterhez tartozó kábel lehet Type1 és Type 2 csatlakozású is. Méretét tekintve lehetnek 3,68 kW, 4 kW vagy 5 $\mathrm{kW}$ teljesítményüek, mindez 1 fázison.

Következőekben szeretnénk ismertetni a rendszer telepítését és müködését. Az inverter váltó áramú oldalát bekötik az otthoni elosztóba, az egyenáramú, napelemes részét pedig bekötik napelemes rendszerbe és a töltökábelen keresztül lehet tölteni az autót. Ez az inverter képes egy úgynevezett Solar Boost technológiát alkalmazni, ami lehetővé teszi, hogy az autót akár 2,5-szer gyorsabban tudjuk tölteni, mint a Mode2-es töltésnél. Ezt úgy teszi lehetővé, hogy az inverter összeadja a napelem teljesítményét az otthoni villamos hálózat szabad teljesítményével. Ha nekünk van otthon szabad 16 A egy fázison akkor, ezt a napelemes teljesítménnyel összeadva akár 32 A-rel tölthetjük az autónkat, mindezt teljesítmény bővítés nélkül. A napelemes oldal annyi energiát fog biztosítani amennyit éppen termel, de maximum 16 A nagyságú áramot. Ez az akár 32 A-es töltés a Mode3 töltési kategóriába sorolandó. A SolarEdge inverterhez tartozik egy monitoring platform, ami mutatja, hogy mennyi volt az az energia, amit a napelemröl közvetlenül az autó akkumulátorába töltöttünk és mennyit vételeztünk a hálózatból a töltés során.

Ez egy otthoni napelemes rendszerről való töltésre volt példa, de létezik olyan megoldás is, amikor egy napelemes töltőállomást használhatunk az autó töltésére. Ezekhez a töltőállomásokhoz nincs szükség elektromos hálózatra, $100 \%$ a nap energiáját használják fel. A napelem által megtermelt energia akkumulátorokban van tárolva pont, mint a szigetüzemü napelemes rendszereknél, így lehetővé téve az éjszakai töltést is. Ezek a rendszerek nem túl bonyolult felépítésủek. A legfontosabb elem természetesen a napelem, ami a szerkezet tetején helyezkedik el, hogy a lehetö legnagyobb felületen tudja érni a napsütés. A napelem alatt egy napkövető hidraulika helyezkedik el, ami a lehetővé teszi, hogy a napelemet mindig a lehető legkedvezőbb szögben érje a fény, így maximalizálva a hatásfokot. Ezt a technológiát egy Envision Solar nevü cég fejlesztette ki és állításuk szerint 1760 km megtételéhez elegendő energiát képes termelni a töltőállomás, igaz azt, hogy ez milyen típusú autó esetében értendő ez a szám nem tisztázták.

További innovatív megoldások, amelyek a napelem/napenergia felhasználását próbálják hasznosítani még kezdetleges fázisban vannak, így azokról még nem érdemes beszélni. (Wagner Solar, 2021; alapjarat.hu, 2021).

Ugyan akkor nem szabad figyelmen kívül hagyni, hogy a napelemek feszültsége a hőmérsékletnövekedés hatására csökken. Emiatt az akkumulátorok töltéséhez szükséges feszültség túlhevült napele- 
mek esetében nem áll rendelkezésre (Bodnár, 2017; Bodnár, 2018). Ahhoz, hogy a napelemek által szolgáltatott feszültség stabilizálható legyen, szükséges egy feszültségkonverter (Boros, 2021).

\section{SOLAR BOOST}

\section{Wagner Solar 2002010}

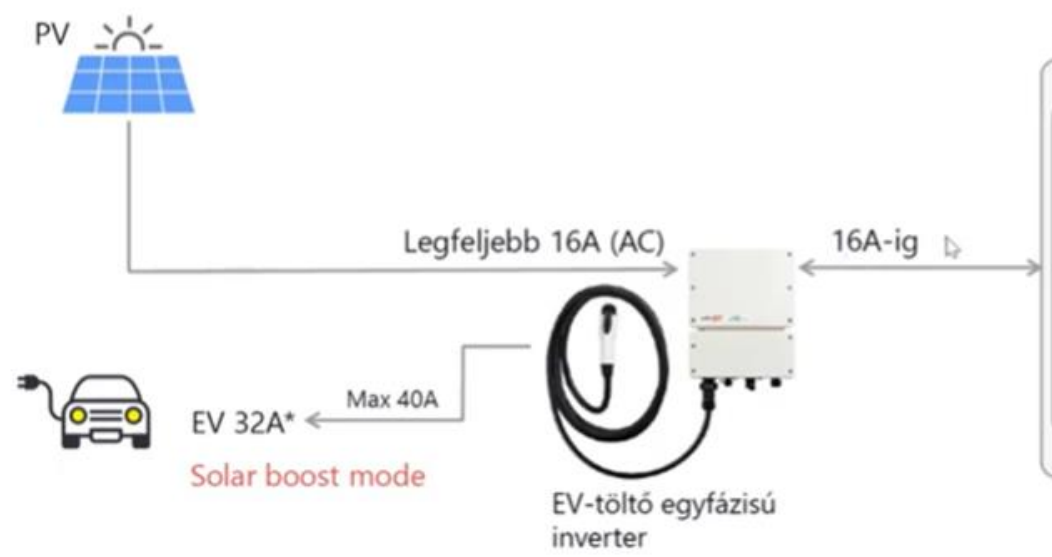

Fó hálózati panel

93

• Európában: IEC62196 szerinti 32A-ra korlátozva és a maximális tōltési arány szerint

\section{9. ábra. Solar Boost üzemmód.}

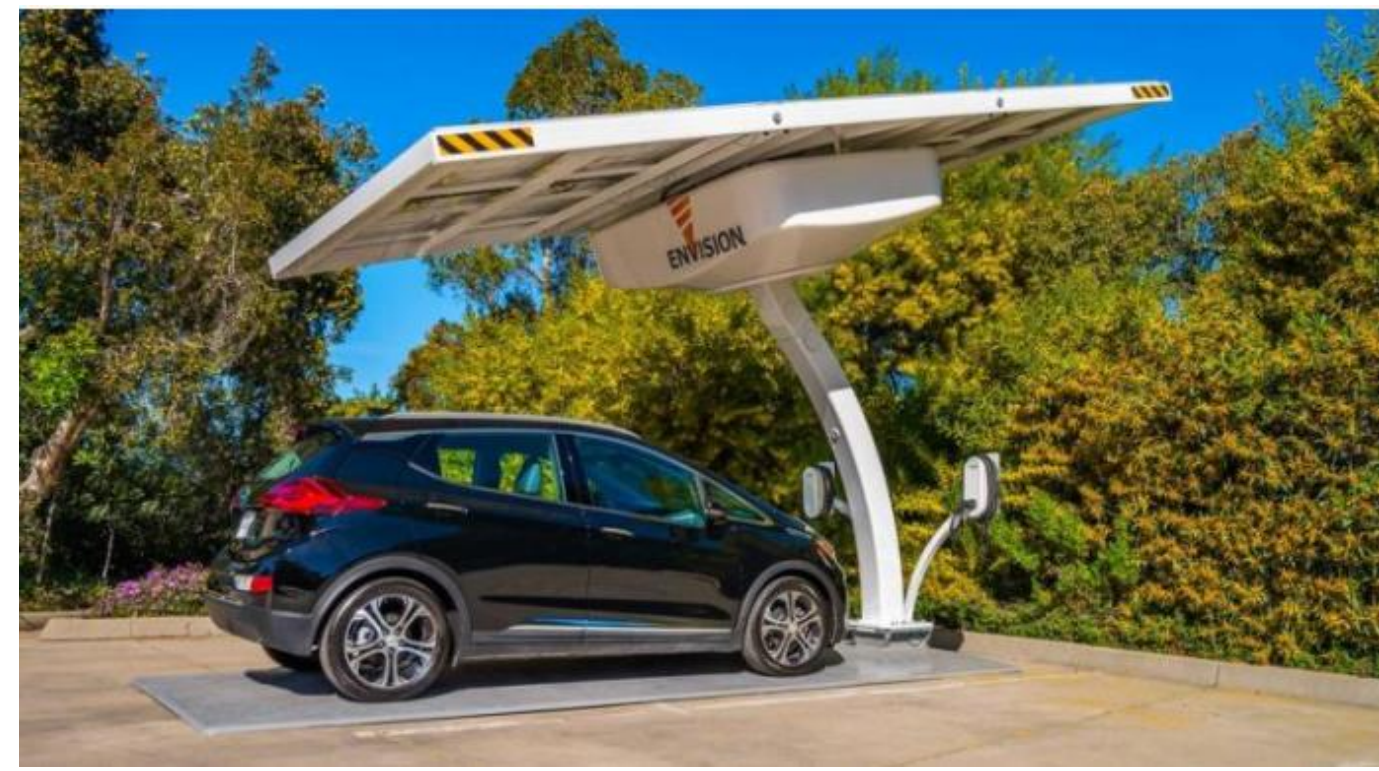

9. ábra. Envision Solar napelemes töltöállomás. 


\section{A Magyar Villamosenergia-Rendszer kiterheltségének vizsgálata}

A villanyautók töltése, főleg, ha az egyenáramú villámtöltést nézzük, eléggé energiaigényes. 2020-ban a KSH adatai szerint 3,92 millió személygépkocsi volt forgalomban hazánkban. Ha az összes személygépkocsi helyett veszünk egy középkategóriás villanyautót (pl. Nissan Leaf, vagy Opel e-Corsa) akkor ez a majdnem 4 millió elektromos autó egyenáramú villámtöltése $50 \mathrm{~kW}$-os villámtöltővel kerekítve majdnem $200 \mathrm{GW}$-os teljesítményt igényelne fél órán keresztül a hálózatból. Ha azt tekintjük, hogy 2020-ban a MAVIR adatai szerint egy átlagos napi csúcsfogyasztás körülbelül $6 \mathrm{GW}$ volt, láthatjuk, hogy ez a mennyiség eltörpül az egyidejü villámtöltéshez szükséges energia mellett. Ámde, az a $200 \mathrm{GW}$ akkor fog fellépni terhelés gyanánt, ha az összes autó tulajdonos egyszerre és mindegyikük villámtöltéssel szeretné feltölteni az autóját. Ez egyáltalán nem életszerü véleményem szerint. Ez a tény azt is megkövetelné, hogy minden autóra jusson egy darab villámtöltő. 2019-ben ebből a töltőből Magyarországon még nagyon kevés, pár tucat volt és valószínűleg sose lesz 10.000-nél de inkább néhány ezernél több villámtöltő Magyarországon, mivel fölösleges lenne a telepítése. Ezekkel a töltőkkel autópályák mentén fogunk találkozni, mivel céljuk, hogy a villanyautóst segítsék minél hamarabbi tovább indulásában. Magyarország nem olyan nagy ország, hogy több ezer ilyen töltő telepítésére legyen szükség, mivel országon belül akár a legnagyobb távolság is megtehető 1-2 töltéssel. Ezért az, hogy 4 millió villámtöltő legyen egyszerre müködésben nem fog megtörténni. Másrészt, az emberek többsége, főleg azok, akik szeretnék kímélni az autó akkumulátorát, nem gyors- vagy villámtöltéssel fogják tölteni az autójukat, hanem otthon, lassú Mode2-es konnektorról történő töltéssel. Egyébként is az autósok többsége ezt a töltési módot használja. Márpedig, ha Mode2-es töltésről beszélünk akkor az emberek többsége 3,6 kW-os töltőt fog használni a jármű töltéséhez. Ebben az esetben körülbelül 14,4 GW energiát igényelne a 4 millió Nissan Leaf töltése 9,5 órán keresztül, ha 0-100\%-ra kéne tölteni az akkumulátoraikat. Ez már közeledik az átlagos napi fogyasztás csúcsértékéhez.

Sajnos Magyarország a számos erőművei ellenére kénytelen viszonylag nagyobb mennyiségủ energiát importálni, hogy el tudja látni a fogyasztói igényeket. 2020-ban a termelt hazai villamos energia csaknem 33,5 TW volt és ehhez még 11,6 TW-nyi energiát voltunk szükségesek importálni. Ez lényegében annak köszönhető, hogy az erőmüvek a nappali csúcs idején nem képesek kielégíteni az igényeket. Viszont az esti órákban, leginkább éjfél és hajnal négy óra között, a fogyasztás jelentősen lecsökken. Az áramszolgáltatás sajátossága, hogy minden pillanatban annyi energiát kell termelni, mint amennyit a fogyasztók igényelnek. Éjszaka csökken a fogyasztás, viszont az energiatermelés mondhatni állandó, mivel az alaperőművek termelését nemigazán lehet ilyen gyorsan szabályozni, figyelni kell a fogyasztás egyensúlyát és szükség esetén be kell avatkozni, hogy a hálózat frekvenciája ne változzon. Ezt vagy az erőművek teljesítményének csökkentésével vagy kapcsolható fogyasztók (pl. kapcsolható bojlerek) segítségével lehet elérni. Az éjszaka jellemző kis igényt az éjszaka töltött elektromos autók tudnák növelni, így a napi energiaigénynek a mozgása sokkal kiegyenlítettebb lenne. Az autó tulajdonos hazaér munka után, felrakja az autót töltőre és reggelig van ideje feltölteni. Mivel egész este áll az autó lényegtelen, hogy gyorstöltéssel este 11-re feltölt vagy lassú töltéssel reggel 6-ra amikor indulni készül a tulaj. Ezért nem lenne szükség óriási teljesítményre a töltésre. A nappali és éjszakai csúcsérték között majdnem 2000 MW különbség van. Ezen a különbségen akár 550.000 villanyautót lehetne tölteni 3,6 kW-os konnektoros töltésről. És ez a napi energia mozgásból adódik.

Most vizsgáljuk meg az éves energia fogyasztását Magyarországnak. 2019-ben 45,4 TWh volt az ország villamosenergia felhasználása, ebből a lakossági felhasználás 11,7 TWh. Ennek ismeretében nézzük meg mennyivel nőne Magyarország teljes villamosenergia felhasználása, ha a 4 millió autónak 25\%-a, azaz minden negyedik autó elektromos autó lenne. Egy átlagos éves futásteljesítmény kb. 10- 
15.000 km közé tehető. Ebben az esetben számoljunk a rosszabb esettel 15.000 km-rel. A sprintmonitor.de oldalról vett adat szerint a Nissan Leaf átlagos fogyasztása $16 \mathrm{kWh} / 100 \mathrm{~km}$. Ezzel számolva 1 millió Nissan Leaf éves villamosenergia felhasználása 2,4 TWh/év.

Ez azt jelenti, hogy 1 millió elektromos autó mindössze 5\%-kal növelné meg a teljes energiafogyasztást. Ez a lakossági fogyasztásnak körülbelül $20 \%$ tenné ki. Ez a százalék eléggé elenyésző a villamosenergia hálózatra nézve, valószínủ nem omlana össze a hálózat ekkora többlet terheléstöl. De ez a számítás 1 millió autó egyidejű töltésére vonatkozik. Ezzel ellentétben 2020 szeptember végén csupán 23.349 zöldrendszámos villanyautó volt forgalomban hazánkban. A legoptimálisabb becslések szerint is az elkövetkezendő 10 évben körülbelül 10-20\%-os növekedés várható a villanyautók számát tekintve. Ez a szám jóval elmarad a számításban lévő 1 millió autótól, aminek az esetében se volt túlságosan nagy az éves fogyasztás túllépése, így pedig a jelenlegi helyzetben és az elkövetkezendő években a villamos hálózat ki fogja bírni a villanyautók töltésének a terhét.

Ha később jobban megközelítjük ezt az 1 milliós számot, a jelenlegi villamos hálózat elbírná a töltés terhét, ha az autó tulajdonosok többsége éjszaka intézni a töltést. Ezzel még a napi teljesítményingadozást is lehetne csökkenteni.

Mivel a mai Magyarországi erőművek így sem képesek tisztán önerőből finanszírozni a szükségletek kielégítésére elegendő energiát, így az a kérdés, hogy elegendő erőmü áll-e rendelkezésre az elektromos autók töltésére nem releváns, tekintve, hogy az ország a jelenlegi helyzetben is folyamatosan energia importálására szorul. (villanyautosok.hu/.../birja-e-a-halozat, 2021; mavir.hu, 2021; villanyautosok.hu/.../rekord-mertekbe-novekedett, 2021; ksh.hu, 2021; e-cars.hu, 2021; villanyautosok.hu/.../mi-az-azevse, 2021)

\section{7. Összefoglalás}

Napjainkban egyre nagyobb hangsúlyt kapnak a nem fosszilis üzemanyagokkal müködő jármüvek, ezek közül is leginkább a villamos hajtású jármüvek. A töltési típusok, módszerek vizsgálatánál, arra a következtetésre jutottunk, hogy az emberek többsége azért vásárol villanyautót, mert otthon, akár napelemről is meg lehet oldani a töltést. A nyilvános töltők hálózata a jövőben biztosan bővülni fog, a gyorstöltők és a villámtöltők hálózata egyaránt, így akár a nagyobb távok megtétele sem lesz probléma villanyautókkal se.

A hálózat kiterheltségének vizsgálatánál az derült ki, hogy jelen számú villanyautók töltése egyáltalán nem terheli túl a rendszert. De még ha 1 millió villanyautó lenne, ami azt jelenti, hogy minden negyedik autó elektromos hajtású, ha az emberek egyszerre szeretnék tölteni az összes jármüvet, akkor, ha este következne be a töltés, a jelen fogyasztás csak kis mértékben nőne. Ám várhatóan ez az 1 milliós szám nem 10-20 év múlva fog bekövetkezni. Ez alatt az idő alatt a magyar villamos hálózat fejlődhet is. Például a Paksi Atomerőmü bővítése, ami várhatóan 2030-ra megvalósul, 2400 MW plusz teljesítményt fog jelenteni a magyar villamosenergia termelésben.

Vélhetően az elkövetkezendő évtizedben a villamos autók száma nem fog olyan mértékben növekedni, hogy töltésük olyan jelentős túlfeszültségeket vagy túlterhelődéseket okozzon a magyar villamoshálózaton, ami veszélyt jelentene, vagy a rendszer összeomlását okozná.

\section{Köszönetnyilvánítás}

A cikkben ismertetett kutató munka az NTP-SZKOLL-20-0022 azonosítószámú „Fókusz'21 - Középpontban a közösség digitális kompetenciák fejlesztése által” projekt keretében valósult meg az Emberi Erőforrások Minisztériuma és az Emberi Erőforrás Támogatáskezelő támogatásával. 


\section{Irodalom}

[1] Boros, R. R., Bodnár, I., Matusz-Kalász, D. (2021). Life cycle assessment of traditional and electric vehicles. Vehicle and Automotive Engineering 3, VAE 2020, Lecture Notes in Mechanical Engineering, 22, 186-193. https://doi.org/10.1007/978-981-15-9529-5_16

[2] Boros, R. R. (2021). LLC rezonáns konverter tervezése és szimulációja. Multidiszciplináris Tudományok, 11(4), 198-207. https://doi.org/10.35925/j.multi.2021.4.24

[3] Bodnár, I. (2017). Transient electrical characteristics of a solar cell in the case of a cooling and non-cooling solar cell. ANNALS of Faculty Engineering Huneodora- International Journal of Engineering, XV(4), 175-178.

[4] Bodnár, I. (2018). Electric parameters determination of solar panel by numeric simulations and laboratory measurements during temperature transient. Acta Polytechnica Hungarica, 15(4), 59-82.

[5] Webinárium. (2021, April 13). Elektromos auto töltés otthon, napelememel. Wagner Solar. https://www.youtube.com/watch?v=pofvf-uqfw8

[6] (2021, April 14). Napelemröl müködő mobil elektromosautó töltöállomás. https://alapjarat.hu/tech/frissitettek-napelemrol-uzemelo-mobil-elektromosauto-toltoallomason

[7] (2021, April 15). Birja-e a hálózat a rengeteg villanyautót? https://villanyautosok.hu/2018/07/04/birja-e-a-halozat-a-rengeteg-villanyautot/

[8] MAVIR adatpublikációk és kiadványok. (2021, April 15). https://www.mavir.hu/web/mavir/adatpublikaciok-es-kiadvanyok

[9] (2021, April 15). Rekord mértékben növekedett a zöld rendszámos autók száma. https://villanyautosok.hu/2020/10/13/rekord-mertekben-novekedett-a-zöld-rendszamos-autokszama/

[10] (2021, April 15). Közúti gépjármü-állomány. https://www.ksh.hu/docs/hun/xstadat/xstadat_eves/I_ode006c.html

[11] (2021, April 08). Elektromos autó töltö típusok és fajták listája. https://e-cars.hu/elektromosauto-tolto-tipusok-es-fajtak-listaja/

[12] (2021, April 09). Mi az az EVSE? https://villanyautosok.hu/2018/01/22/mi-az-az-evse/

[13] (2021, April 08). E-töltö kisokos e-on. https://www.eon.hu/content/dam/eon/eonhungary/documents/e-mobilitas/E_tolto_kisokos_online_FINAL.pdf

[14] (2021, April 08). Elektromos autó töltö típusok. https://villanyautosok.hu/elektromostoltoallomasok-magyarorszagon/elektromos-auto-tolto-tipusok/

[15] (2021, April 08). Elektromos autó töltö típusok, fontos technikai tudnivalók. https://gateconnection.hu/elektromos-auto-tolto-tipusok-fontos-tudnivalok/ 